2017-12-15

\title{
Assessing the presence of marine toxins in bivalve molluscs from southwest India
}

\section{Turner, AD}

http://hdl.handle.net/10026.1/10153

10.1016/j.toxicon.2017.11.001

Toxicon

Elsevier

All content in PEARL is protected by copyright law. Author manuscripts are made available in accordance with publisher policies. Please cite only the published version using the details provided on the item record or document. In the absence of an open licence (e.g. Creative Commons), permissions for further reuse of content should be sought from the publisher or author. 


\section{Accepted Manuscript}

Assessing the presence of marine toxins in bivalve molluscs from southwest India

Andrew D. Turner, Monika Dhanji-Rapkova, Stephanie Rowland-Pilgrim, Lucy M. Turner, Ashwin Rai, Moleyur N. Venugopal, Indrani Karunasagar, Anna Godhe

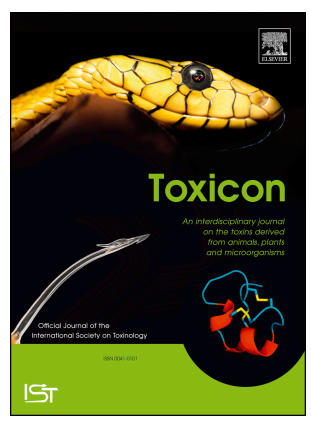

PII:

S0041-0101(17)30339-2

DOI:

10.1016/j.toxicon.2017.11.001

Reference: TOXCON 5758

To appear in: Toxicon

Received Date: 22 September 2017

Revised Date: 1 November 2017

Accepted Date: 3 November 2017

Please cite this article as: Turner, A.D., Dhanji-Rapkova, M., Rowland-Pilgrim, S., Turner, L.M., Rai, A., Venugopal, M.N., Karunasagar, I., Godhe, A., Assessing the presence of marine toxins in bivalve molluscs from southwest India, Toxicon (2017), doi: 10.1016/j.toxicon.2017.11.001.

This is a PDF file of an unedited manuscript that has been accepted for publication. As a service to our customers we are providing this early version of the manuscript. The manuscript will undergo copyediting, typesetting, and review of the resulting proof before it is published in its final form. Please note that during the production process errors may be discovered which could affect the content, and all legal disclaimers that apply to the journal pertain. 
1 Assessing the presence of marine toxins in bivalve molluses

2 from southwest India

3

4

\author{
Andrew D. Turner*l, Monika Dhanji-Rapkova ${ }^{l}$, Stephanie Rowland-Pilgrim ${ }^{l}$, Lucy M. \\ Turner $^{2,3}$, Ashwin Rai ${ }^{4}$, Moleyur N. Venugopal ${ }^{4}$, Indrani Karunasagar ${ }^{5}$ and Anna Godhe ${ }^{2}$ \\ ${ }^{1}$ Centre for Environment, Fisheries and Aquaculture Science (Cefas), Barrack Road, The Nothe, \\ Weymouth, Dorset, DT4 8UB, United Kingdom. \\ ${ }^{2}$ Department of Marine Sciences, University of Gothenburg, Box 461, SE 40530 Göteborg, Sweden. \\ ${ }^{3}$ Marine Biology and Ecology Research Centre, Plymouth University, Drake Circus, Plymouth, \\ Devon, PL4 8AA, United Kingdom. \\ ${ }^{4}$ Department of Fishery Microbiology, Karnataka Veterinary Animal and Fisheries Sciences \\ University, College of Fisheries, Mangalore, 575002, India. \\ ${ }^{5}$ UNESCO-MIRCEN for Medical and Marine Biotechnology, Nitte University Centre for Science \\ Education and Research (NUCSER), Nitte University, Mangalore 575018, India. \\ *Corresponding author - Andrew.turner@ cefas.co.uk
}

\begin{abstract}
The south west coast of India has been showing a steady increase in shellfish cultivation both for local consumption and fishery export, over recent years. Perna viridis and Crassostrea madrasensis are two species of bivalve molluscs which grow in some selected regions of southern Karnataka, close to the city of Mangalore. In the early 1980s, shellfish consumers in the region were affected by intoxication from Paralytic Shellfish Poison present in local bivalves (clams and oysters) resulting in hospitalisation of many, including one fatality. Since then, there have been no further reports of serious shellfish intoxication and there is little awareness of the risks from natural toxins and no routine monitoring programme in place to protect shellfish consumers. This study presents the findings from the first ever systematic assessment of the presence of marine toxins in mussels and oysters grown in four different shellfish harvesting areas in the region. Shellfish were collected and subjected to analysis for ASP, PSP and lipophilic toxins, as well as a suite of non-EU regulated toxins such as tetrodotoxin and selected cyclic imines. Results revealed the presence of low levels of PSP toxins in oysters throughout the study period. Overall, total toxicities reached a maximum of $10 \%$ of the EU regulatory limit of $800 \mu \mathrm{g} \mathrm{STX} \mathrm{eq/kg.} \mathrm{Toxin}$ profiles were similar to those reported from the 1980 outbreak. No evidence was found for significant levels of ASP and lipophilic toxins, although some cyclic imines were detected, including gymnodimine. The results indicated that the risk to shellfish consumers during this specific study period would have been low. However, with historical evidence for extremely high levels of PSP toxins in molluscs, there is a strong need for routine surveillance of shellfish production areas for marine toxins, in order to mitigate against human health impacts resulting from unexpected harmful algal blooms, with potentially devastating socioeconomic consequences.
\end{abstract}

\title{
Keywords
}

Shellfish, India, Lipophilic toxins, Paralytic Shellfish Poisoning, Amnesic Shellfish Poisoning, LC-FLD, LC-UV, LC-MS/MS 
51

52

53

54

55

56

57

58

59

60

61

62

63

64

65

66

67

68

69

\section{Introduction}

Marine biotoxins comprise various groups of naturally-occurring compounds present in Harmful Algal Blooms (HAB), a natural phenomenon caused by the overgrowth of marine phytoplankton (Visciano et al., 2016). Through filter feeding behaviour, bivalve molluscs can accumulate toxins from harmful algae (Landsberg, 2002; Hallegraef, 2003; Llewellyn et al., 2006; Deeds et al., 2008). Some groups of toxins are known to cause human sickness after being consumed (Mead et al., 1999; Erdner et al., 2008). ASP is caused by domoic acid (DA), a cyclic tricarboxylic amino acid, and potentially other toxic DA isomers. Following human consumption of DA-contaminated shellfish, symptoms can be gastrointestinal and/or neurological, leading potentially to fatalities (Jeffrey et al., 2004). In comparison, Paralytic Shellfish Toxins (PST) comprise a family of more than 50, mostly hydrophilic, structural analogues of the tetrahydropurine saxitoxin (Wiese et al., 2010). Following ingestion by humans, these highly potent neurotoxins can induce symptoms such as nausea, numbness, breathing difficulties, paralysis, and at high enough concentrations, death (EFSA, 2009a). Tetrodotoxin (TTX) produces a near-identical toxic response in mammals as saxitoxin and its presence has recently been proven in Asian (Kodama et al., 1993; McNabb et al., 2014) and European bivalve molluscs (Turner et al., 2015a, Vlamis et al., 2015). Lipophilic toxins (LTs) include compounds such as the DSP toxins: okadaic acid (OA), dinophysis toxin-1 and -2 (DTX1 and DTX2), including their ester derivatives (often termed DTX3), the azaspiracids (AZAs), yessotoxins (YTXs), pectenotoxins (PTXs) and a number of cyclic imines including the spirolides (SPXs) and gymnodimine (GYM) (McNabb et al., 2005). The acute effects of DSP and AZP are less severe than the effects from PSP and ASP, with no known fatalities resulting from intoxication following ingestion of any of the regulated lipophilic toxins (Blanco et al., 2005). A range of toxicological effects have however been reported, including tumour promotion and carcinogenicity, so serious long-term health effects cannot be discounted following exposure to DSP toxins (Valdiglesias et al., 2013). Cyclic imines are known to be fast acting toxins following direct injection into mice, but there is no evidence for acute oral toxicity to date in humans (EFSA, 2010; Hess et al., 2013).

Pseudo-nitzschia spp. are the causative organisms for production of DA leading potentially to ASP (Bates et al., 1989; Lundholm et al., 1994). Paralytic shellfish toxins (PST) are produced by several species of phytoplankton including Alexandrium spp., Gymnodinium catenatum and Pyrodinium bahamense (van Dolah, 2000). Phytoplankton responsible for DSP include Prorocentrum lima, and a range of Dinophysis species (Yasumoto et al., 1980; Morton et al., 2009; Reguera et al., 2014). Yessotoxins are known to be produced by Protoceratium reticulatum and Lingulodinium polyedrum (Visciano et al., 2016). Azaspiracids, the most recently discovered of the regulated marine toxin classes, are now known to be produced by the dinoflagellate Azadinium spinosum (Krock et al., 2009a; Tillmann et al., 2009) together with a number of other species of Azadinium (Tillmann et al., 2010, 2011). Algal imines such as gymnodimine, pinnatoxins and spirolides have been isolated from dinoflagellates Gymnodinium sp., Vulcanodinium rugosum and A. ostenfeldi/peruvianum respectively (Hu et al., 2001, Moestrup et al., 2009; Seki et al., 1995). As opposed to all the dinoflagellate sources for these toxins, TTX and a number of related analogues (TTXs) are shown to be produced by a range of marine bacterial species. Genera proposed include Vibrio, Bacillus, Aeromonas, Alteromonas, and Pseudomonas (Yasumoto et al., 1988; Wu et al., 2005; Nogouchi et al., 2006, 2008; Wang et al., 2008; Chau et al., 2011, Turner et al., 2015a), although links to occurrence of Prorocentrum cordatum/minimum have been recently hypothesised (Vlamis et al., 2015).

Along the coast of India there have been reports of the occurrence of several phytoplankton species. These include PSP toxin producing species such as Alexandrium spp., 
including A. tamarense, A. minutum and A. catenella, and Gymnodinum catenatum. Among identified DSP toxin producers were Dinophysis species, such as D.caudata, D.acuta and D. acuminata. DA producers were represented here by Pseudonitzchia spp. A PSP outbreak has been reported previously from the Mangalore region of SW India, which resulted in human intoxication including one fatality (Karunasagar et al., 1984; Karunasagar et al., 1990; Segar et al., 1989). Two other PSP outbreaks have also been reported following consumption of toxic bivalves, with one in 1981 from Kalpakkam, near Chennai, on the east Indian coast involving a low number of people (unpublished data) and a second in September 1998 from Vizhijam, near Trivandrum, when over 500 people were hospitalised and at least five deaths were reported (Karunasagar et al., 1998). To date there have been no reported occurrences of ASP or DSP intoxication in humans anywhere in India. With an absence of any routine regulatory monitoring programme for shellfish toxins in India, there is a scarcity of data describing the prevalence of marine toxin occurrence in shellfish.

The objectives of this study were therefore to assess the presence of domoic acid, paralytic shellfish toxins, tetrodotoxin and lipophilic toxins in mussels and oysters harvested in the marine waters of Mangalore, SW India. The assessment included the analysis of shellfish species harvested over a period of 13 months from four different shellfish harvesting beds in the Mangalore region. The detection of any hydrophilic or lipophilic biotoxins would provide links to toxic phytoplankton previously reported in Indian waters together with evidence for the potential risk to shellfish consumers from a wide range of natural shellfish toxins.

\section{Materials and methods 2.1 Samples}

The southern Karnataka coastline consists of long stretches of wide sandy beaches with a few rocky outcrops bisected by several major rivers originating from the western Ghats. Where these discharge into the Arabian Sea they form a network of estuaries, wetlands, mudflats and mangroves, often sheltered from the ocean itself behind sandspits (Sowmya and Jayappa, 2016). At several places along the coast, rich natural beds of $P$. viridis occur in the intertidal and subtidal rocky areas (Sasikumar and Krishnamoorthy, 2010; Sasikumar and Krishnakumar, 2011; Sasikumar et al., 2011). Oysters are less abundant, being present in only some of the major estuarine areas (Rao and Rao, 1985). 110 samples of shellfish tissue were analysed during this study, consisting of both green mussels (Perna viridis) and Indian backwater oysters (Crassostrea madrasensis). The four marine monitoring sites incorporated in the study were Gangoli, Mulki, Sasthana and Someshwar (Figure 1). At Gangoli, mussels were collected from the Panchagangavali estuary and at Someshwar from the open coast. Oysters were collected from the Padukere (Sasthana) and Nandini (Mulki) estuarine areas. Shellfish were collected using the same methods twice a month over the 13month study period (Table S1). Typically, 25-50 individuals were collected for each sample. The samples were transported to the laboratory of the Department of Fishery Microbiology, College of Fisheries, Mangalore and were frozen, until required for sample processing.

\subsection{Reagents and chemicals}

Certified reference toxins for PST, DA and LTs were obtained from the Institute of Biotoxin Metrology at the National Research Council of Canada (NRCC, Halifax, Nova Scotia, Canada). TTX CRM was obtained from Cifga (Lugo, Spain). Microcystins and nodularin were obtained from Enzo Life Sciences, Exeter, UK. All reagents for preparation of LC-MS/MS mobile phases were LC-MS grade, and those used for LC-UV were HPLC grade or better. Trifluoroacetic acid ( $\geq 99 \%$ purity), glacial acetic acid ( $\geq 99 \%$ purity), formic acid 
( $\geq 99 \%$ purity) and $25 \%$ ammonia $\left(\mathrm{NH}_{4}\right)$ were all LC-MS grade and purchased from SigmaAldrich (Poole, Dorset, UK).

\subsection{Shellfish extraction}

For each sample, a suitable number of individuals were shucked to generate a minimum of $100 \mathrm{~g}$ shellfish tissue. Shellfish meat was homogenized and sub-samples taken for each of the extraction methods. For each batch of samples extracted, a procedural blank consisting of deionised water was prepared. Extracts were stored $\left(-20{ }^{\circ} \mathrm{C}\right)$ until shipped in one batch to the Cefas laboratory for toxin analysis. Extracts were received after three days of transportation in good condition with temperatures maintained $<0^{\circ} \mathrm{C}$.

PSP and TTX extraction was conducted using the method of Turner et al. (2015c). $5 \pm 0.01 \mathrm{~g}$ of each sample was extracted in $5 \mathrm{~mL}$ of $1 \%$ acetic acid in polypropylene centrifuge tubes. The tissues and solvents were vortexed for $90 \mathrm{~s}$ before adding capped tubes to a boiling water bath for 5 mins $\pm 10 \mathrm{~s}$. Samples were subsequently cooled by placing in cold running water for a minimum of 5 mins. After cooling, tubes were vortexed $(90 \mathrm{~s})$ and centrifuged for 10 minutes at $4500 \mathrm{rpm}$, prior to decanting the supernatant into a $15 \mathrm{~mL}$ tube.

LT extraction was conducted using a scaled-down version of EURL (2015). $1 \pm 0.01 \mathrm{~g}$ of each homogenised shellfish tissue sample was added to a $15 \mathrm{~mL}$ centrifuge tube. $4.5 \mathrm{~mL}$ of $100 \%$ methanol was transferred to the homogenate and the tubes capped before vortex mixing for $3 \mathrm{~min}$. Extracts were centrifuged at $4500 \mathrm{rpm}$ for $8 \mathrm{~min}$ at $20^{\circ} \mathrm{C}$. The supernatant was decanted into a new $15 \mathrm{~mL}$ tube for each sample extract and PB, before adding a second $4.5 \mathrm{~mL}$ aliquot of $100 \%$ methanol to the tube containing the pellet. The shellfish solvent mix was again vortex-mixed, centrifuged and the supernatants from both extraction steps combined before diluting to a total volume of $10 \mathrm{~mL}$.

ASP extraction was conducted using a method based on that of Quilliam et al., 1995. $2 \pm 0.01 \mathrm{~g}$ of each homogenised shellfish tissue sample was weighed into a $15 \mathrm{~mL}$ polypropylene centrifuge tube. $4 \mathrm{~mL}$ of $50 / 50(\mathrm{v} / \mathrm{v})$ methanol/water was pipetted into sample tubes and vortexed for $2 \mathrm{~min}$. Extracts were then centrifuged $(3500 \mathrm{rpm})$ for $20 \mathrm{~min}$ at $20^{\circ} \mathrm{C}$. The supernatant for each shellfish sample and PB was transferred into separate $15 \mathrm{~mL}$ polypropylene tubes. A further $4 \mathrm{~mL}$ aliquot of 50/50 (v/v) methanol/water was added to the shellfish pellet tube, vortexed and centrifuged, before decanting into the tube containing the first supernatant. The supernatant was diluted to a total volume of $10 \mathrm{~mL}$ with $50 / 50(\mathrm{v} / \mathrm{v})$ methanol/water and gently shaken until thoroughly mixed.

\subsection{Clean-up and analysis}

SPE clean-up of acetic acid extracts prior to analysis for PST and TTX was performed following the method of Boundy et al., (2015). SPE eluents were vortex-mixed and diluted 3:1 with acetonitrile in polypropylene LCMS-grade autosampler vials, before placing into the autosampler (set at $+10^{\circ} \mathrm{C}$ ) for analysis using an Acquity I-Class UPLC system coupled to a Waters Xevo TQ-S tandem mass spectrometer (Waters, Manchester, UK). UPLC was conducted using a $1.7 \mu \mathrm{m}, 2.1 \times 150 \mathrm{~mm}$ Waters Acquity BEH Amide UPLC column in conjunction with a Waters VanGuard BEH Amide guard cartridge, held at $+60^{\circ} \mathrm{C}$.

Chromatographic and MS/MS parameters used were exactly those detailed by the validated method of Turner et al., 2015c (Table 1). Samples were run together with six-point external calibration solutions prepared from CRM stocks. Toxicity equivalence factors (TEFs) and relative response factors (RRFs) for PST were those described by Turner et al., 2015c (Table 2). For TTX analysis the modified method of Turner et al., (2017a) was followed, with detection conducted using six-level calibration standards prepared from TTX stock solution. Method performance characteristics are those reported by Turner et al., 2015c and Turner et al., 2017a. 
Methanolic extracts for each sample was thawed and filtered through a $0.2 \mu \mathrm{m}$ nylon syringe filter and an aliquot taken for LC-MS/MS analysis of LT. A second $1.0 \mathrm{~mL}$ aliquot of the raw extract was transferred into a $2 \mathrm{~mL}$ screw capped vial for alkaline hydrolysis, by adding $125 \mu \mathrm{L}$ of $2.5 \mathrm{M} \mathrm{NaOH}$. After vortex mixing, the vial was heated to $76 \pm 2{ }^{\circ} \mathrm{C}$ for 40 min, cooled to room temperature before the addition of $125 \mu \mathrm{L}$ of $2.5 \mathrm{M} \mathrm{HCl}$. The hydrolysed extract was then ready for LC-MS/MS analysis, using an Acquity Ultra Performance Liquid Chromatography (UPLC) system coupled to a Waters Xevo TQ tandem mass spectrometer. UPLC was performed using a Waters BEH C18 column $(50 \times 2.1 \mathrm{~mm}, 1.7 \mu \mathrm{m})$ with a VanGuard BEH C18 $(5 \times 2.1 \mathrm{~mm}, 1.7 \mu \mathrm{m})$ guard cartridge. The analytical method used was as described by Turner and Goya, 2015 (Table 1). Toxin concentrations were quantified against six-point external calibrations prepared from NRCC standards. Concentrations of free toxins were determined in non-hydrolysed extracts, with hydrolysed extracts used for assessment of total OA-group toxins (free plus esterified toxins). LTs were confirmed as being detected when both the quantitative and qualifier MRM transitions were present at the expected toxin retention time, with a concentration above the method limit of quantitation, taken in this study as $4 \mu \mathrm{g} / \mathrm{kg}$ per toxin.

The 50/50 (v/v) methanol/water extracts were filtered through $0.2 \mu \mathrm{m}$ syringe nylon membrane filters into glass autosampler vials. Chromatographic separation for ASP analysis was conducted using a Phenomenex (Manchester, UK) Kinetex PFP $5.0 \mu \mathrm{m} 4.6$ x $150 \mathrm{~mm}$ HPLC column. LC-UV analysis was performed using Agilent 1100/1200 modules (Agilent, Manchester, UK): quaternary pump, vacuum degasser, autosampler, column over and UVdiode array detector $(242 \mathrm{~nm})$. Samples were run alongside external calibration standards for detection and quantitation purposes, with a method LOQ equivalent to $0.2 \mathrm{mg}$ domoic acid per $\mathrm{kg}$ shellfish tissue.

\section{Results \\ 3.1 PSP and TTX toxins \\ 3.1.1 Total PST and TTX}

PST were detected in all four shellfish harvesting areas during the study, in both mussel and oyster samples. The highest concentrations were quantified in oysters from Mulki and Sasthana, with values reaching $>75 \mu \mathrm{g}$ STX eq/kg in both sites, with a maximum concentration of $82 \mu \mathrm{g}$ STX eq/kg in oysters from Sasthana, collected in December 2015. Significantly lower total PST concentrations were obtained in the mussels collected from both Gangoli and Someshwar, with the highest concentration $\sim 8 \mu \mathrm{g}$ STX eq/kg in the mussels collected from Gangoli during December 2014. Figure 2 illustrates the temporal variability in total PST quantified in both species across the four sites. At both oyster sites, very low $(<5 \mu$ g STX eq $/ \mathrm{kg})$ levels of PST were presented between December 2014 and March 2015. Subsequently from the end of March 2015 onwards, at both sites, a sudden increase in PSP toxicity was found, with toxins remaining in the flesh consistently until the end of the study period in January 2016. Much lower levels were quantified in the mussels from the two other sites, with the highest concentrations determined in shellfish harvested during early 2015. No TTX was detected in any of the samples from any of the four shellfish harvesting areas.

\subsubsection{PST profiles}

Oyster samples from Mulki and Sasthana were found to contain a range of PST analogues, including C1\&2, GTX2\&3, GTX1\&4, dcSTX, STX and GTX5. No C3\&4, dcGTX2\&3, dcGTX1\&4, NEO, dcNEO or doSTX was detected in any of the shellfish samples. In terms of toxicity equivalents, the profiles were dominated by GTX1 (mean proportion $\sim 60 \%$ ), followed by GTX4, GTX2, GTX3 and dcSTX around the same proportion 
(mean 10-15\%). The N-sulfocarbamoyl analogues, C1\&2 and GTX5 were present at lower relative levels, with mean proportions around 4-6\%. Figure 3 illustrates the mean toxin profiles from November 2014 to January 2016 in oysters from each of the two harvesting areas. The results indicate the near identical profiles at both sites. Due to the overall low toxicity in the mussel samples, the toxin profiles proportions were not determined. However, toxins detected included dcSTX, STX, GTX2, C1 and C2. Notably GTX1, the dominant PST congener in the oyster samples, was not detected.

\subsection{Lipophilic toxins}

Analysis of methanolic extracts of mussels and oysters showed a near complete absence of regulated lipophilic marine toxins from the four study areas. No MRM peaks were identified for any of the OA-group toxins, AZAs and YTXs. Esterified OA-group toxins were absent in the hydrolysed extracts. The only LT identified was PTX2, present at very low concentrations $(0.4 \mu \mathrm{g} / \mathrm{kg})$ in one oyster sample from Mulki harvested in Jan 2015. No other shellfish samples from this study contained PTX2 or any other pectenotoxins.

The 3 cyclic imines (CIs) analysed in these samples were SPX1 (13-desMeC spirolide), SPXG (20-Me SPXG spirolide) and GYM (gymnodimine). Of these three, SPX1 and GYM were identified, with 42 samples $(\sim 38 \%)$ containing detectable levels of SPX1 and all 110 containing GYM. Concentrations of SPX1 were low ranging from 1.7-2.0 $\mu \mathrm{g} / \mathrm{kg}$.

Figure 4 summarises the GYM concentrations in both shellfish species throughout the yearlong study, with the higher levels found in oysters in comparison to mussels. Concentrations in oysters ranged between 9.0 and $40.2 \mu \mathrm{g} / \mathrm{kg}$, with elevated values between Nov 2014 to Jan 2015 (mean $24.4 \mu \mathrm{g} / \mathrm{kg}$ ). Mussels contained GYM at lower and more consistent concentrations throughout the study $(4.7-9.5 \mu \mathrm{g} / \mathrm{kg}$; mean $=6.8 \mu \mathrm{g} / \mathrm{kg})$.

\subsection{ASP}

Out of the 100 bivalve mollusc samples analysed in this study, only two showed trace levels of DA. One mussel sample from Gangoli, collected in Nov 2014 showed DA at 0.16 $\mathrm{mg} / \mathrm{kg}$, and an oyster sample harvested from Mulki in Feb 2015 presented a similar level of $0.18 \mathrm{mg} / \mathrm{kg}$. Both results were below method LOQ and close to the LOD $(0.2 \mathrm{mg} / \mathrm{kg})$. No other samples showed chromatographic peaks indicative of DA.

\section{Discussion}

In relation to the PST regulatory action limit of $800 \mu \mathrm{g}$ STX eq $/ \mathrm{kg}$, the maximum concentrations of PST determined in this study were low. The highest concentrations of toxins quantified reach approximately $10 \%$ of action limit, thereby representing a low overall risk to shellfish consumers based on the data generated in this study. The recent work of Turner et al., (2016), showed evidence for low PST uptake (maximum $31 \mu \mathrm{g} \mathrm{STX} \mathrm{eq/kg)} \mathrm{in}$ mussels in mesocosms containing Alexandrium minutum at 100,000 cells/L held at conditions (temperature $28^{\circ} \mathrm{C}$ and $32^{\circ} \mathrm{C}$; salinity $35 \mathrm{PSU}$ and $31 \mathrm{PSU}$ ) similar to the environmental conditions recorded in Mangalore during this study (Table S1). The highest concentrations were determined in oysters from Mulki and Sasthana, in comparison to the mussels from Gangoli and Someshwar. Without any of the sites containing both shellfish species, however, it is not clear whether the significant differences recorded are due to the differences in toxin uptake rates between the species, or relate more to the conditions at individual sites. Previous reports of PSP in shellfish from this region showed PSP toxicity rising to $1200 \mu \mathrm{g}$ STX eq/ $\mathrm{kg}$ in oysters (Crassostrea cucullata) and $3400 \mu \mathrm{g}$ STX eq/ kg in clams (Meretrix casta) (Karunasagar et al., 1984). Several PSP intoxications in humans were reported including one fatality. Cooked clams obtained from the homes of affected people and clams collected from the natural bed were analysed by MBA and found to contain PSP at a level of $3370 \mu \mathrm{g}$ STX 
eq/kg (Karunasagar et al., 1984). Since then, there have been no further reports of PSP intoxication in local consumers. Other than the reports of low levels of PSP toxicity in molluscs during 1985 and 1986 (Segar et al., 1989), there have been no further reports of PST accumulation in bivalve molluscs from this region, although the absence of a routine monitoring programme may explain this non-detection.

The results from this study show the almost uniform presence of PST in oysters between April and December 2015. Blooms of dinoflagellates along the west coast of India are thought by some authors to proliferate between September and October, although this may relate in part to the lower number of phytoplankton analyses conducted during monsoon season (D'Silva et al., 2012). Other authors, however, have evidenced a dominance of diatoms in the water column until December, with dinoflagellates increasing their overall contribution during February to March (Asplund et al., 2011). Mean toxin profiles in oysters from both shellfish harvesting areas were nearly identical, with a clear dominance of GTX1, together with the presence of other gonyautoxins (GTX2-5), dcSTX, STX and C1\&2. Toxin profiles determined from the 1983 outbreak samples showed a similar dominance of gonyautoxins (GTX1-4) and C1\&2, as well as lower concentrations of STX and dcSTX. In addition, the results showed the presence of NEO and dcGTX2\&3, as well as C3\&4, toxins not detected in this study (Karunasagar et al., 1990). These differences may relate to the higher overall toxicity levels found in the 1983 samples in comparison to those from the current study. In addition, the analysis of the outbreak samples was performed using a postcolumn oxidation LC-FLD method, so may have been subject to interferences for some of the toxins present at low concentrations. Finally, there may have been species-related differences in the toxin profiles as a consequence of bacterial or enzymatic toxin transformation within tissues (Bricelj and Shumway, 1998; Cembella et al., 1994; Jaime et al., 2007; Oshima, 1995; Sakamoto et al., 2000; Sato et al., 2000; Wiese et al., 2010; Turner et al., 2012).

At the time of the toxin profile identification in outbreak samples, authors used the qualitative toxin profile, in tandem with the findings of cysts morphologically similar to $A$. cohorticula, to postulate that Alexandrium species was the probable causative organism for PSP occurrence (Karunasagar et al., 1990). Since then, the long-term monitoring of phytoplankton communities in this region has revealed complex interactions between hydrographic parameters such as sea surface temperatures, rainfall, wind speed and water column mixing and phytoplankton occurrence. Nevertheless, whilst phytoplankton communities have been highly dynamic in the past decades, the presence of the potentially PSP-producing genera, Gymnodinium has been found on a regular basis (Godhe et al., 2015). G. catenatum itself was reported to occur both in planktonic and cyst forms in 1996 from waters in the Mangalore region (Godhe et al., 1996). A. minutum has also been found by microscopic and polymerase chain reaction (PCR) detection methods in field samples from Mangalore during 1999 (Godhe et al., 2001). Other toxin producing species identified along the west coast include A. minutum, A. tamarense and A. catenella (Shahi et al., 2015). Certainly the absence of PST analogues related to G. catenatum such as C3\&4, GTX6 and dcNEO (Vale, 2010; Costa et al., 2015) in this study, indicates that the causative organisms in Mangalore during 2015 are possibly Alexandrium spp.

No evidence was found for the presence of TTX in any samples, even during December when $V$. parahaemolyticus abundance has been shown to be highest in this region (Rehnstam-Holm et al., 2014), although significant variability in $V$. parahaemolyticus abundance has been previously recorded even during times of stable water column temperature and salinity (Rehnstam-Holm and Godhe, 2012). It is noted however that oysters from this study were collected in the shallow sublittoral zone and mussels were collected by hand divers from deeper water sites. Consequently, none of the shellfish from this study were present in the intertidal zones, where exposure to the high temperatures during low tides may 
potentially result in the increase of bacterial levels, and therefore promote TTX production (Turner et al., 2017b).

Domoic acid was detected at trace levels only $(<0.2 \mathrm{mg} / \mathrm{mg})$, showing little evidence for accumulation of toxins from DA-producing phytoplankton in this region. The presence of organisms such as Pseudonitzchia sp. (Härnström et al., 2007; Shahi et al., 2015) and Nitzschia sp. (Härnström et al., 2009; D’Silva et al., 2012; Shahi et al., 2015) has been previously reported around the west coast of India during period of diatom dominance in the water column, although the temporal variability in bloom occurrence has been highlighted (Shahi et al., 2015) and the toxicity of such species from this region has never been tested. As such the risk, until further toxicity assessment is conducted, should not be discounted.

The EU-regulated LTs were notable by their near-complete absence from both mussel and oyster samples. This was surprising given the prevalence of at least six species of the genus Dinophysis in $40 \%$ of water samples around the coast over a long-term monitoring period, between 1990 and 2010 (Godhe et al., 2015). The detection of trace amounts of the pectenotoxin PTX2 in one sample indicates the presence of D. acuminata (Kamiyama and Suzuki, 2009), but such a species is generally also associated with production of OA-group toxins (Tango et al., 2004; Reguera et al., 2012, 2014). Species identified along the western coast of India include $D$. acuminata, $D$. caudata, D. miles, D. norvegica, $D$. tripos and $D$. rotundata (Shahi et al., 2015), with several of these associated with DSP toxin production. Over a 21-year period of assessment, Dinophysis spp. were detected in 19 years ( 90\%), with variable (moderate to high cell densities) between years. Moreover, cell counts were positively correlated with sea surface temperatures (SST) during this period. The highest presence of Dinophysis previously recorded was during 1996-1998, which coincided with the strongest El Nino Southern Oscillation event of the $20^{\text {th }}$ century (Godhe et al., 2015), during which elevated SST resulted in a significant increase in net phytoplankton abundance. Mean annual SST values were $>30^{\circ} \mathrm{C}$ during this period, before decreasing to $\sim 29^{\circ} \mathrm{C}$ around 2005 and then increasing to $\sim 30^{\circ} \mathrm{C}$ in 2010 (Godhe et al., 2015). During this study, SST ranged from $26.0^{\circ} \mathrm{C}$ to $29.5^{\circ} \mathrm{C}$, with a mean of $27.8^{\circ} \mathrm{C}$. Therefore, it is likely that lower cell densities of Dinophysis spp. were present between 2014 and 2015, although it is noted that there is no phytoplankton data available to our knowledge. Dinophysis species present in the marine waters around Mangalore have not to date been cultured and tested for toxin production capability. Until proven otherwise, it is to be inferred that the Dinophysis present around Mangalore may potentially be non-toxic strains.

The consistently low levels of the spirolide SPX-1 throughout the study samples is of little if any consequence to human food safety, given the lack of evidence for oral toxicity from cyclic imines (Richard et al., 2001; Davidson et al., 2015). Various Alexandrium species have been identified as SPX producers, including A. ostenfeldii and more recently the morphologically similar, but usually smaller, A. peruvianum (Cembella et al., 2000; Touzet et al., 2008). A. peruvianum has been identified along the western coast of India (Shahi et al., 2015) although the toxin concentrations determined in this study perhaps indicate that phytoplankton producers are present at only very low densities, which in addition may not be resolved from the presence of other Alexandrium species. Gymnodimine has been linked to neurotoxicity in mice following i.p injection (Davidson et al., 2015) and has been isolated from Gymnodinium mikimotoi (Seki et al., 1995), later renamed as Karenia selliformis (Haywood et al., 2004). Production of GYM has also been demonstrated in European strains of A. ostenfeldii (Salgado et al., 2015). To date GYM has been identified in shellfish from Northern and Southern Africa, New Zealand (Krock et al., 2009; Davidson et al., 2015), and more recently Mexico (Garcia-Mendoza et al., 2014). Gymnodinium spp. have previously been reported as re-occurring in the water column of the study areas over the past few decades (Godhe et al., 2015), particularly during the warmer months. As discussed in the 
context of PST results, blooms of dinoflagellates in this region are generally at their maximum density between September and October (D'Silva et al., 2012). GYM concentrations in oysters, however, showed a maxima around December to January, 2-3 months after the expected peak of phytoplankton blooms. Moreover, the increase in GYM was not observed during the end of 2015. The higher concentrations of GYM in oysters from this study in comparison to mussels are interesting given the general consensus that many marine toxins accumulate to significantly higher levels in mussels than many other species of mollusc (e.g. Bricelj and Shumway, 1998). As with the PST results, the inter-species differences for GYM may either relate to species-specific uptake effects or to differences in the water column during shellfish feeding and toxin uptake.

Overall the results have indicated a relatively low level of risk from biotoxins for the majority of the study period. With maximum total PST concentrations around $10 \%$ of the current EU regulatory MPL of $800 \mu \mathrm{g}$ STX eq/kg, no significant concentrations of regulated lipophilic marine toxins and only trace levels of domoic acid detected, there is good evidence that the shellfish grown and consumed during 2015 were relatively free from harmful toxins. However, with past work showing significant inter-annual differences in toxin phytoplankton production in Mangalore, more analysis on a larger number of samples would be required over a longer time period to generate a better understanding of risk to shellfish consumers in this region of India. Given the significant growth in the local shellfish industry including international export, and the socio-economic impacts this brings to the region, it is critical that routine monitoring of bivalve mollusc production areas is implemented, to help mitigate against these potentially life-threatening natural toxins.

\section{Acknowledgements}

The authors are grateful for help with sample preparation provided by the technical staff at the Department of Fishery Microbiology, College of Fisheries, Mangalore during this study. This study was funded by the Swedish Research Council to IK and AG (348-2013-6489) and the Cefas Seedcorn fund to AT and MDR (DP345).

\section{References}

Aligizaki, K., Katikou, P., Milandri, A. and Diogene, J. (2011). Occurrence of palytoxingroup toxins in seafood and future strategies to complement the present state of the art. Toxicon. 57:390-399

Anderson, D. M.; Cembella, A. D.; Hallegraeff, G. M. (2012) Progress in understanding harmful algal blooms: paradigm shifts and new technologies for research, monitoring and management. Annu. Rev. Mar. Sci. 2012, 4, 143-176.

Anon. (2004). Regulation (EC) No 854/2004 of the European Parliament and of the Council of $29^{\text {th }}$ April 2004 laying down specific rules for the organisation of official controls on products of animal origin intended for human consumption. Official Journal of the European Union. L226, 83-127.

Anon. (2005a). AOAC Official Method 959.08. Paralytic Shellfish Poison. Biological method. Final action. In: AOAC Official methods for analysis, $18^{\text {th }}$ Edition Chapter 49: Natural toxins (chapter ed. M.W. Truckses), pp. 79-80. Gaithersburg, MD, USA: AOAC International 
Anon. (2005b). Regulation (EC) No 2074/2005 of the European Parliament and of the Council of 5 December 2005 laying down implementing measures of certain products under Regulation (EC) No 835/2004 of the European Parliament and of the Council and for the organisation of official controls under Regulation (EC) No 854/2004 of the European Parliament and of the Council and Regulation (EC) No 882/200 of the European Parliament and of the Council, derogating from Regulation (EC) No 852/2004 of the European Parliament and of the Council and amending Regulations (EC) No 853/2004 and (EC) No 854/2004. Official Journal of the European Union L338. Annex III, Chapter III. pp 40-41

Anon. (2005c). AOAC Official method 2005.06 Quantitative determination of Paralytic Shellfish Poisoning Toxins in shellfish using pre-chromatographic oxidation and liquid

Anon (2011a). AOAC Official method 2011.02 Determination of Paralytic Shellfish Poisoning Toxins in mussels, clams, oysters and scallops. Post-column oxidation method (PCOX). First action 2011. Gaithersburg, MD, USA: AOAC International.

Anon. (2011b). AOAC Official method 2011.27. Paralytic Shellfish Toxins (PSTs) in Shellfish, Receptor Binding Assay. Gaithersburg, MD, USA: AOAC International.

Arakawa, O., Hwang, D-F., Taniyama, S. And Takatani, T. 2010. Toxins of pufferfish that cause human intoxications. Coastal Environmental and ecosystem issues of the East China Sea., 227-244

Asplund, M.E., Rehnstam-Holm, A-S., Atnur, V., Raghunath, P., Saravanan, V., Härnström, Collin, B., Karunasagar, I. and Godhe, A. (2011) Water column dynamics of Vibrio in relation to phytoplankton community composition and environmental conditions in a tropical coastal area. Environmental Microbiology. 13(10), 2738-2751

Bates, S. S.; Bird, C. J.; De Freitas, A. S. W.; Foxall, R. A.; Gilgan, M.; Hanic, L. A.; Johnson, G. R.; McCulloch, A. W.; Odense, P.; Pocklington, R.; Quilliam, M. A.; Sim, P. G.; Smith, J. C.; Subba

Rao, D. V.; Todd, E. C. D.; Walter, J. A.; Wright and J. L. C. Pennate. Diatom Nitzschia pungens as the Primary Source of Domoic Acid, a Toxin in Shellfish from Eastern Prince Edward Island, Canada. Can. J. Fish Aquat. Sci . 1989 , 46 , 1203 - 1215.

Blanco, J., Álvarez, G., \& Uribe, E. 2007. Identification of Pectenotoxins in Plankton, Filter Feeders, and Isolated Cells of a Dinophysis acuminata with an Atypical Toxin Profile, From Chile. Toxicon, 49(5), 710-716

Blanco, J., Moroño, A. and Fernández, M.L. (2005) Toxic episodes in shellfish, produced by lipophilic phycotoxins: an overview. Revista Galega de Recursos Marinos (Monog.): 1, 1-70

Botana, A.M., Otero, P., Rodriguez, P., Alfonso, A. and Botana, L.M. (2012) Current situation on analysis of marine toxins. Rev. Anal. Chem. 2012. Doi: 10.1515/revac-2012-0020

Boundy, M.J., Selwood, A.I., Harwood, D.T., McNabb, P.S. and Turner, A.D. (2015). Development of a sensitive and selective liquid chromatography-mass spectrometry method for high throughput analysis of paralytic shellfish toxins using graphitic carbon SPE. $J$. Chrom. A. 1387, 1-12 
499

500

501

502

503

504

505

506

507

508

509

510

511

512

513

514

515

516

517

518

519

520

521

522

523

524

525

526

527

528

529

530

531

532

533

534

535

536

537

538

539

540

541

542

543

544

545

546

Bricelj, M.V. and Shumway, S.E. (1998) Paralytic shellfish toxins in bivalve molluscs: occurrence, transfer kinetics and biotransformation. Reviews in Fisheries Science. 6(4), 315383

Chau, R., Kalaitzis, J.A. and Neilan, B.A. 2011. On the origin and biosynthesis of Tetrodotoxin. Aquatic toxicology., 104, 61-72

Chorus, I., Bartram, J., (1999). Toxic Cyanobacteria in Water: A Guide to Their Public Health Consequences, Monitoring and Management. World Health Organization/E\&FN Spon/Routledge, London.

Cembella, A.D.; Lewis, N.I.; Quilliam, M.A. (2000) The marine dinoflagellate Alexandrium ostenfeldii (Dinophyceae) as the causative organism of spirolide shellfish toxins. Phycologia, $39,67-74$

Cembella, A.D., Shumway, S.E., Larocque, R., (1994). Sequestering and putative biotransformation of paralytic shellfish toxins by the sea scallop Placopecten magellanicus: seasonal and spatial scales in natural populations. J. Exp. Biol. Ecol. 180, 1-22.

Central Marine Fisheries Research Institute, Kochi (2012a) Marine Fisheries Census 2010 Part II. 7 Kerala. CMFRI; Kochi, Kochi.

Central Marine Fisheries Research Institute, Kochi (2012b) Marine Fisheries Census 2010 Part II. 7 Karnataka. CMFRI; Kochi, Kochi.

Chorus, I.; Falconer, I.R.; Salas, H.J.; Bartram, J. (2000) Health risks caused by freshwater cyanobacteria in recreational waters. J. Toxicol. Environ. Health B, 3, 323-347.

Costa, P.R., Robertson, A. and Quilliam, M.A. (2015) Toxin profile of Gymnodinium catanatum (Dinophyceae) from the Portuguese coast, as determined by liquid chromatography tandem mass spectrometry. Marine Drugs. 12. Doi:10.33690/md110x000x

D'Silva, M.S., Anil, A.C., Naik, R.K. and D'Costa, P.M. (2012) Algal bloom: a perspective from the coasts of India. Nat. Hazards. 63, 1225-1253

Davidson, K., Baker, C., Higgins, C., Higman, W., Swan, S., Veszelovszki, A. and Turner, A.D. (2015) Potential threats posed by new of emerging marine biotoxins in UK waters and examination of detection methodologies used for their control: cyclic imines. Marine Drugs. $13,7087-7112$

Deeds, J. R., Landsberg, J. H., Etheridge, S. M., Pitcher, G. C. and Longan, S. W. (2008). Non-traditional vectors for paralytic shellfish poisoning. Marine Drugs 6, 308-348

Dickey, R., Jester, E., Granade, R., Mowdy, D., Moncreiff, C., Rebarchik, D., Robl, M., Musser, S. And Poli, M. (1999). Monitoring brevetoxins during a Gymnodinium breve red tide: comparison of sodium channel specific cytotoxicity assay and mouse bioassay for determination of neurotoxic shellfish toxins in shellfish extracts. Natural Toxins. 7: 157-165 
EFSA (2008a) Opinion of the Scientific Panel on Contaminants in the Food chain on a request from the European Commission on marine biotoxins in shellfish - okadaic acid and analogues, The EFSA Journal (2008) Journal number, 589, 1-62.

European Food Safety Authority. 2008b. Opinion of the Scientific Panel on Contaminants in the Food chain on a request from the European Commission on Marine biotoxins in shellfish - azaspriracids group. The EFSA Journal 2008; 723: 1-52.

EFSA (2008c) Opinion of the Scientific Panel on Contaminants in the Food chain on a request from the European Commission on marine biotoxins in shellfish - yessotoxin group, The EFSA Journal (2008) Journal number, 907, 1-62.

EFSA (2009a). Scientific Opinion of the Panel on Contaminants in the Food Chain on a request from the European Commission onMarine Biotoxins in Shellfish - Saxitoxin Group. EFSA J. 1019, 1-76.

EFSA (2009b) Scientific Opinion of the Panel on Contaminants in the Food Chain on a request from the European Commission on marine biotoxins in shellfish - pectenotoxin group. The EFSA Journal (2009) 1109, 1-47.

EFSA (2009c) Scientific Opinion of the Panel on Contaminants in the Food Chain on a request from the European Commission on marine biotoxins in shellfish - Summary on regulated marine biotoxins 2009. The EFSA Journal 1306, 1-23.

Erdner, D. L. et al. (2008). Centers for oceans and human health: A unified approach to the challenge of harmful algal blooms. Environ. Health 7, S2-1-S2-17

European Reference Laboratory for marine biotoxins (EURLMB, 2015). EU harmonised standard operating procedure for determination of lipophilic marine biotoxins in molluscs by LC-MS/MS, version 5Jan 2015.

http://www.aecosan.msssi.gob.es/AECOSAN/docs/documentos/laboratorios/LNRBM/ARCH IVO2EU-Harmonised-SOP-LIPO-LCMSMS_Version5.pdf (Accessed 19th April 2017)

Ferreiro, S. F., Carrera, C., Vilariño, N., Louzao, M. C., Santamarina, G., Cantalapiedra, A. G., et al. (2015). Acute cardiotoxicity evaluation of the marine biotoxins OA, DTX-1 and YTX. Toxins 7, 1030-1047. doi: 10.3390/toxins7041030

Garcia-Mendoza, E., Sanchez-Bravo, Y.A., Turner, A.D., Blanco, J., O’Neill, A., ManceraFlores, J., Perez-Brunius, P., Rivas, D., Almazan-Becerril, A. and Pena-Manjarrez, J.L. (2014) Lipophilic toxins in cultivated mussels (Mytilus galloprovincialis) from Baja California, Mexico. Toxicon. 90, 111-123

Gibble, C.M., Kudela, R.M. (2014). Detection of persistent microcystin toxins at the land-sea interface in Monterey Bay, California. Harmful Algae 39, 146-153.

Godhe, A., Karunasagar, I and Karunasagar, I. (1996) Gymnodinium catenatum on the west coast of India. Harmful Algae News. The Intergovernmental Oceanographic Commission of UNESCO. No. 15, p1 
Godhe, A., Otta, S.K., Rehnstam-Holm, A-S., Karunasagar, I and Karunasagar, I. (2001) Polymerase chain reaction in detection of Gymnodinium mikimotoi and Alexandrium minutum in field samples from southwest India. Marine Biotechnology. 3, 152-162

Godhe, A., Narayanaswamy, C., Klais, R., Venkatesha Moorthy, K.S., Ramesh, R., Rai, A. and Venkataswamy Reddy, H.R. (2015) Long-term patterns of net phytoplankton and hydrography in coastal SE Arabian Sea: what can be inferred from genus level data?Estuarine, Coastal and Shelf Science. 162, 69-75

Hallegraeff GM. 1993. A review of harmful algal blooms and their apparent global increase. Phycologia 32:79-99

Hallegraef G.M. (2003). Harmful Algal Blooms: A Global Overview. in Manual on Harmful Marine Microalgae, G.M. Hallegraef, D.M. Anderson \& A.D. Cembella (Eds), UNESCO, Paris, France, pp 25-49

Härnström, K., Godhe, A., Saravanan, V.., Karunasagar, I., Karunasagar, I. and RehnstamHolm, A-S. (2007) Tropical phytoplankton community development in mesocosms inoculated with different life stages. Mar. Ecol. Prog. Ser. 346, 75-88

Härnström, K., Karunasagar, I. and Godhe, A. (2009) Phytoplankton species assemblages and their relationship to hydrographic factors - a study at the old port in Mangalore, coastal Arabian Sea. Indian Journal of Marine Science. 38(2), 224-234

Haywood, A.J.; Steidinger, K.A.; Truby, E.W.; Bergquist, P.R.; Bergquist, P.L.; Adamson, J.; MacKenzie, L. (2004) Comparative morphology and molecular phylogenetic analysis of three new species of the genus Karenia (Dinophyceae) from New Zealand. J. Phycol. 40, $165-179$.

Hess, P., Abadie, E., Hervé, F., Berteaux, T., Séchet, V., Aráoz, R., et al. (2013). Pinnatoxin $\mathrm{G}$ is responsible for atypical toxicity in mussels (Mytilus galloprovincialis) and clams (Venerupis decussata) from Ingril, a French Mediterranean lagoon. Toxicon 75, 16-26. doi: 10.1016/j.toxicon.2013.05.001

Hu, T.; Burton, I. W.; Cembella, a. D.; Curtis, J. M.; Quilliam, M. a.; Walter, J. a.; Wright, J. L. C. (2001) Characterisation of spirolides A, C and 13-desmethyl C, new marine toxins isolated from toxic plankton and contaminated shellfish. J. Nat. Prod. 64, 308-312.

Ibelings, B.W., Bruning, K., De Jonge, J., Wolfstein, K., Pires, L.D., Postma, J. and Burger, T. (2005). Distribution of microcystins in a lake foodweb: no evidence for biomagnification. Microbial ecology, 49(4), pp. 487500 .

Immanuel, S. (2008) Adoption of oyster culture by women in Kerala. Fishery technology, 45(2): 237-242.

Jaime, E., Gerdts, G., Luckas, B., (2007). In vitro transformation of PSP toxins by different shellfish tissues. Harmful Algae 6, 308-316. 
Jeffery, B., Barlow, T., Moizer, K., Paul, S., and Boyle, C. (2004). Amnesic shellfish poison. Food Chem. Toxicol. 42, 545-557. doi: 10.1016/j.fct.2003.11.010

Kaladharan, P. and Asokan, P.K. (2011) Shellfish Poisoning. Report from Calicut Research Centre of CMFRL. 72-74

Kalaitzidou, M., Filliousis, G., Petridou, E., Economou, V.,Theodoridis, A. and Aggelidis, P., 2015. Isolation of Toxic MarineCyanobacteria and Detection of Microcystins in Thermaikos Gulf in CentralMacedonia in Greece. In HAICTA pp. 832-841

Kamiyama, T., \& Suzuki, T. 2009. Production of dinophysistoxin-1 and pectenotoxin-2 by a culture of Dinophysis acuminata (Dinophyceae). Harmful Algae, 8(2), 312-317

Karunasagar, I., Gowda, H.S.V., Subburaj, M., Venugopal, M.N. and Karunasagar, I. (1984) Outbreak of Paralytic Shellfish Poisoning in Mangalore, West coast of India. Current Science. 53(5), 247-249

Karunasagar, I., Karunasagar, I., Oshima, Y. and Yasumoto, T. (1990) A toxin profile for shellfish involved in an outbreak of Paralytic Shellfish Poisoning in India. Toxicon. 28(7) $868-870$

Karunasagar I, Joseph B, Philipose KK, Karunasagar I (1998) Another outbreak of PSP in India. Harmful Algae News, An IOC Newsletter on toxic algae and algal blooms 17:1

Kodama, M., Sato, S., and Ogata, T. 1993. Alexandrium tamarense, as a source of Tetrodotoxin in the scallop Patinopecten yessoensis. Toxic Phytoplankton Blooms in the Sea., 5th International conference on toxic marine phytoplankton: papers. 3, 401-406

Kodama, M., Sato, S., Sakamoto, S. and Ogata, T. 1996. Occurrence of Tetrodotoxin in Alexandirum tamarense, a causative dinoflagellate of paralytic shellfish poisoning. Toxicon., 34, 1101-1105

Kripa, V. and Mohamed, K.S.(2008) Green mussel, Perna viridis, farming in Kerala, India technology diffusion process and socioeconomic impacts. J. World Aquacult. Soc. 39 (5), 612624.

Krock, B.,Tillmann, U.,John, U.,Cembella, A. D. (2009a) Characterization of azaspiracids in plankton size-fractions and isolation of an azaspiracid-producing dinoflagellate from the North Sea Harmful Algae 2009, 8, 254-263.

Krock, B.,Tillmann, U.,John, U.,Cembella, A. D. (2009b) Confirmed identification of gymnodimine in oysters from the west coast of South Africa by liquid chromatographytandem mass spectrometry. African Journal of Marine Science. 2009, 31(1), 113-118.

Landsberg, J. H. (2002). The effects of harmful algal blooms on aquatic organisms. Rev. Fish. Sci. 10, 113-390

Llewellyn, L., Negri, A. \& Robertson, A. (2006). Paralytic shellfish toxins in tropical oceans. Toxin Reviews 25, 159-196 
Lundholm, N.,Skov, J.,Pocklington, R.; Moestrup, O .(1994) Domoic acid, the toxic amino acid responsible for amnesic shellfish poisoning, now in Pseudonitzschiaseriata(Bacillariophyceae) in Europe. Phycologia, 33 , 475 - 478.

McNabb, P., Selwood, A.I. and Holland, P.T. (2005) Multiresidue method for determination of algal toxins in shellfish: single-laboratory validation and interlaboratory study. J.AOAC $88(3), 761-772$

McNabb, P.S., Taylor, D.I., Ogilvie, S.C., Wilkinson, L., Anderson, A., Hamon, D., Wood, S.A. and Peake, B.M. 2014. First detection of Tetrodotoxin in the bivalve Paphies autralis by liquid chromatography coupled to triple quadrupole mass spectrometry with and without precolumn reaction. J. AOAC International. 97(2), 325-333

Mead, P. S. et al. (1999). Food-related illness and death in the United States. Emerg. Infect. Dis. 5, 607-625

Miller, M.A., Kudela, R.M., Mekebri, A., Crane, D., Oates, S.C., Tinker, M.T., Staedler, M., Miller, W.A., Toy-Choutka, S., Dominik, C., and Hardin, D. (2010). Evidence for a novel marine harmful algal bloom: cyanotoxin (microcystin) transfer from land to sea otters. PLoS One 5, e12576.

Moestrup, Ø.,Akselmann, R.,Fraga, S.; Hansen, G.; Hoppenrath, M.,Iwataki, M.; Komarek, J.,Larsen, J.,Lundholm, N.,Zingone, A. (eds.)(2009 onwards) IOC-UNESCO Taxonomic Reference List of Harmful Micro Algae http://www.marinespecies.org/hab. Accessed on-line $7^{\text {th }}$ April 2017.

Mohamed, K. S., Muthiah, C., Nagaraja, D. and Kumar, G.S. (1998) Initiation of marine mussel cultureactivities in Dakshina Kannada district, Karnataka.Marine Fisheries Information Service T \& E Series155:10-15.

Mohamed, K.S., Kripa, V., Asokan, P.K., Sasikumar, G., Venkatesan, V., Jenni, B., Alloycious, P.S., Chinnadurai, S., Ragesh, N., Prema, D. (2016) Development of bivalve farming as a source of income generation for women's self-help groups in coastal India. In: Sustainable intensification of aquaculture in the Asia-Pacific region. Documentation of successful practices. Food and Agriculture Organization of the United Nations, Thailand, pp. $82-92$.

Morton, S.L., Vershinin, A., Smith, L.L., Leighfield, T.A., Pankov, S. and Quilliam, M.A. (2009) Seasonality of Dinophysis spp. And Prorocentrum lima in Black Sea phytoplankton and associated shellfish toxicity. Harmful Algae., 8, 629-636

Murata, M., Shimitami, M., Sugitani, H., Oshima, Y. and Yasumoto, T. (1982) Isolation and structural elucidation of the causative toxin of the diarrhetic shellfish poisoning, Nippon Suisan Gakkaishi, 48: 549-52.

Noguchi, T., Arakawa, O., Takatani, T., 2006a. Toxicity of pufferfish Takifugu rubripes cultured in netcages at sea or aquaria on land. Comp. Biochem. Physiol. Part D 1, 153-157.

Noguchi, T and Arakawa, O. 2008. Tetrodotoxin - distribution and accumulation in aquatic organisms, and cases of human intoxication. Marine Drugs., 6, 220-242 
Ogino, J., Kumagai, M. and Yasumoto, T. .1997. Toxicologic evaluation of yessotoxins. Nat. Toxins. 5: 255-259

Oshima, Y., (1995). Chemical and enzymatic transformation of paralytic shellfish toxins in marine organisms. In: Lassus, P., Arzul, G., Erard, E., Gentien, P., Marcaillou, C. (Eds.), Harmful Marine Algal Blooms. Lasoisier Science Publishers, Paris, pp. 475-480.

Quilliam, M.,A.,Xie, M. and Hardstaff, W.R. (1995). Rapid extraction and clean up for liquid chromatography determination of domoic acid in unsalted seafood. J. AOAC International $78,(2), 543-554$.

Rao, G.S. and Rao, K.S. (1985) Survey of clam and oyster resources of some Karnataka estuaries. Indian J. Fish., 32 (1), 74-89.

Rasmussen, S.A., Anderson, A.J.C., Andersen, N.G., Nielsen, K.F., Hansen, P.J. and Larsen, T.O. (2016) Chemical diversity, origin and analysis of phycotoxins. J. Nat. Products. DOI: 10.1021/acs.jnatprod.5b01066

Reguera, B., Velo-Suarez, L., Raine, R. and Park, M.G. (2012) Harmful Dinophysis species: a review. Harmful Algae., 14, 87-106

Reguera, B., Riobó, P., Rodriguez, F., Diaz, P.A., Pizarro, G., Paz, B., Franco, J.M. and Blanco, J. (2014) Dinophysis toxins: causative organisms, distribution and fate in shellfish. Mar. Drugs., 12, 394-461

Rehnstam-Holm, A.S. and Godhe, A. (2012) Dynamics of Vibrio spp. in relation to phytoplankton community composition and environmental conditions. International Symposium Pathogenic Vibrio spp. in Nothern European Waters Maj 31. Juni 12012. Koblenz Tyskland. DOI: 10.5675/BfG_Veranst_2012.4p. 59-63

Rehnstam-Holm, A.S., Atnur, V. and Godhe, A. (2014) Defining the niche of Vibrio parahaemolyticus during pre- and post-monsoon seasons in the coastal Arabian Sea. Microb. Ecol. 67, 57-65

Richard, D., Arsenault, E., Cembella, A. and Quilliam, M.A. (2001) Investigations into the toxicology and pharmacology of spirolides, a novel group of shellfish toxins. In: Harmful Algal Blooms 2000 (Eds: Hallegraeff, G.M., Blackburn, S.I., Bolch, C.J. and Lewis, R.J) Intergovernmental Oceanographic Commission of UNESCO, Paris, 383-386

Rodriguez, P., Alfonso, A., Vale, C., Alfonso, C., Vale, P., Tellez, A. and Botana, L.M. 2008. First toxicity report of tetrodotoxin and 5,6,11-TrideoxyTTX in the Trumpet Shell Charonia lampas lampas in Europe. Anal. Chem., 80(14), 5622-5629

Satake, M., Ofuji, K., Naoki, H., James, K.J., Furey, A., McMahon, T., Silke, J. and Yasumoto, T. (1998) Azaspiracid, a new marine toxin having unique spiro ring assemblies, isolated from Irish mussels, Mytilus edulis, J. Am. Chem. Soc., 120: 9967-8. 
Sato, S., Sakai, R., Kodama, M., (2000). Identification of thioether intermediates in the reductive transformation of gonyautoxins into saxitoxins by thiols. Bioorg. Med. Chem. Lett. 10, 1787-1789.

Sakamoto, S., Sato, S., Ogata, T., Kodama, M., (2000). Formation of intermediate conjugates in the reductive transformation of gonyautoxins to saxitoxins by thiol compounds. Fish. Sci. $66,136-141$.

Salgado, P.; Riobó, P.; Rodríguez, F.; Franco, J.M.; Bravo, I (2015). Differences in the toxin profiles of Alexandrium ostenfeldii (Dinophyceae) strains isolated from different geographic origins: Evidence of paralytic toxin, spirolide, and gymnodimine. Toxicon, 103, 85-98

Sasikumar, G. and Krishnamoorthy, M. (2010) Aquaculture planning for suspended bivalve farming systems: The integration ofphysiological response of green mussel with environmental variability in siteselection. Indian J. Mar. Sci. 39(3): 434-444.

Sasikumar, G. and Krishnakumar, P.K. (2011) Aquaculture planning for suspended bivalve farming systems: The integration ofphysiological response of green mussel with environmental variability in siteselection. Ecological indicators. 11: 734-740.

Sasikumar, Geetha and Krishnamoorthy, M and Krishnakumar, P K and Bhat, G S (2011) Accumulation of trace metals in green mussel Perna viridis in the shellfish harvesting environment along southern Karnataka coast. Indian Journal of Fisheries, 58 (1). pp. 53-58.

Sasikumar, G., Kumar, G.S., Shridhara, B., Nataraja, G.D., Rohit, P., Mohamed, K.S., Asokan, P.K. and Karamathulla, S.P. (2014) Demonstartion of mussel farming in Karnataka: A success story. Fishing chimes, 34 (4): 31-33.

Segar K, Karunasagar I, Karunasagar I (1989) Dinoflagellate toxins in shellfishes along the coast of Karnataka. In: Joseph MM (ed) The First Indian Fisheries Forum Proceedings, Asian Fisheries Society, Indian Branch, Mangalore, pp 389-390

Seki, T.; Satake, M.; Mackenzie, L.; Kaspar, H. F.; Yasumoto, T. (1995) Gymnodimine, a new marine toxin of unprecedented structure isolated from New Zealand oysters and the dinoflagellate Gymnodinium sp. Tetrahedron Lett. 36, 7093-7096.

Shahi, N., Godhe, A., Mallik, S.K., Härnström, K. and Nayak, B.B. (2015) The relationship between variation of phytoplankton species composition and physico-chemical parameters in northern coastal waters of Mumbai, India. Indian Journal of Geo-Marine Science. 44(5), 1-12

Sotton, B., Anneville, O., Cadel-Six, S., Domaizon, I., Krys, S. and Guillard, J., 2011. Spatial match between Planktothrix rubescens and whitefish in a mesotrophic peri-alpine lake: Evidence of toxins accumulation. Harmful Algae, 10(6), pp. 749-758.

Soymya, K. and Jayappa, K.S. (2016) Environmental sensitivity mapping of the coast of Karnataka, westcoast of India. Ocean and coastal management. 121, 70-87

Tango, P., Butler, W., Lacouture, R., GOshorn, D., Magnien, R., Michael, B., Hall, S., Browhawn, K., Wittman, R., Beatty, W. (2004) In: Steidinger, K.A., Landsberg, J.H., Tomas, 
C.R., Vargo, G.A (Eds.) An unprecedented bloom of Dinophysis acuminata in Chesapeake Bay. Florida Fish and Wildlife Conservation Commission, FIO and ICO UNESCO, pp 358360

Testai, E., Buratti, F.M., Funari, E., Manganelli, M., Vichi, S., Arnich, N., Biré, R., Fessard, Valerie, and Sialehaamoa, A. (2016) Review and analysis fo occurrence, exposure and toxicity of cyanobacteria toxins in food. EFSA supporting publication 2016:EN-998. 309 pp.

Tillmann, U., Elbrächter, M., Krock, B., John, U., Cembella, A.D., (2009). Azadinium spinosum gen. et sp nov (Dinophyceae) identified as a primary producer of azaspiracid toxins. Eur. J. Phycol. 44, 63-79.

Tillmann, U., Elbrächter, M., John, U., Krock, B., Cembella, A.D., (2010). Azadinium obesum (Dinophyceae), a new nontoxic species in the genus that can produce azaspiracid toxins. Phycologia 49, 169-182.

Tillmann, U., Salas, R., Gottschling, M., Krock, B., O’Driscoll, D., Elbrächter, M., 2011. Amphidoma languida sp. nov. (Dinophyceae) reveals a close relationship between Amphidoma and Azadinium. Protist. http://dx.doi.org/10.1016/j.protis.2011.10.005.

Touzet, N.; Franco, J.M.; Raine, R. (2008) Morphogenetic diversity and biotoxin composition of Alexandrium (Dinophyceae) in Irish coastal waters. Harmful Algae, 7, 782-797

Turner, A.D., Lewis, A.M., Hatfield, R.G., Galloway, A.W. and Higman, W.A. (2012) Transformation of paralytic shellfish poisoning toxins in Crassostrea gigas and Pecten maximus reference materials. Toxicon. $60,1117-1134$

Turner, A.D. and Goya, A.B. (2015) Occurrence and profiles of lipophilic toxins in shellfish harvested from Argentina. Toxicon. 102, 32-42

Turner, A.D., Powell, A., Schofield, A., Lees, D.N. and Baker-Austin, C. (2015a). Detection of the pufferfish toxin Tetrodotoxin in European bivalves, England, 2013 to 2014.

Eurosurveillance. 20(2): pii $=21009$

Turner, A.D., Higgins, C., Higman, W. and Hungerford, J. (2015b). Potential threats posed by tetrodotoxins in UK waters: examination of detection methodology used in their control. Marine Drugs. 13, 7357-7376

Turner, A.D., McNabb, P.S., Harwood, T.S., Selwood, A.I. and Boundy, M.J. (2015c) Single laboratory validation of a multi-toxin UPLC-HILIC-MS/MS method for quantitation of paralytic shellfish toxins in bivalve shellfish. J. AOAC International. 98(3), 609-621

Turner, L.M., Alsterberg, C., Turner, A.D., Girisha, S.K., Rai, A., Havenhand, J.N., Venugopal, M.N., Karunasagar, I. and Godhe, A. (2016) Pathogenic marine microbes influence the effects of climate change on a commercially important tropical bivalve. Nature Scientific Reports. 6:32413. Doi: 10.1030/srep32413

Turner, A.D., Boundy, M.J. and Dhanji-Rapkova, M. (2017a). Development and singlelaboratory validation of a liquid chromatography tandem mass spectrometry method for quantitation of Tetrodotoxin in mussels and oysters. J. AOAC International. 100(5) 1-14. 
893

894

895

896

897

898

899

900

901

902

903

904

905

906

907

908

909

910

911

912

913

914

915

916

917

918

919

920

921

922

923

924

925

926

927

928

929

930

931

932

933

934

935

936

937

938

939

940

941

942

Turner A.D., Dhanji-Rapkova, M., Coates, L., Bickerstaff, L., Milligan, S., O’Neill, A., Faulkner, D., McEneny, H., Baker-Austin, C., Lees, D.N. and Algoet, M. (2017b). Detection of Tetrodotoxin Shellfish Poisoning (TSP) toxins and causative factors in bivalve molluscs from the UK. Marine Drugs. 15, 277; doi:10.3390/md15090277

Van Dolah, 2000. Marine algal toxins: origins, health effects and their increased occurrence. Environ. Health Perspect. 108(suppl 1): 133-141

Vareli, K., Jaeger, W., Touka, A., Frillingos, S., Briasoulis, E. and Sainis, I. (2013) Hepatotoxic seafood poisoning (HSP) due to microcystins: a threat from the ocean? Marine Drugs. 11, 2751-2768

WHO (2011) World Health Organisation, ed. 2011. Guidelines for drinking-water quality, 4th ed. Geneva, Switzerland: WHO Press.

Vlamis, A., Katikou, P., Rodriguez, I., Rey, V., Alfonso, A., Papazacharious, A., Zacharaki, T., Botana, A.M. and Botana, L.M. 2015. First detection of Tetrodotoxin in Greek Shellfish by UPLC-MS/MS potentially linked to the presence of the dinoflagellate Prorocentrum minimum. Toxins. 7, 1779-1807

Wiese, M.; D’ Agostino, P. M.; Mihali, T. K.; Moffitt, M. C.; Neilan, B. A. (2010)

Neurotoxic alkaloids: saxitoxin and its analogs. Mar. Drugs, 8 , 2185- 2211.

Van Dolah, F.M. (2000) Marine algal toxins: origins, health effects and their increased occurrence. Health Perspectives., 108 (supplement 1), 133-141

Valdiglesias, V.; Prego-Faraldo, M.V.; Pasaro, E.; Mendez, J.; Laffon, B. Okadaic acid: More than a diarrheic toxin. Mar. Drugs 2013, 11, 4328-4349.

Vale, P. (2010) Metabolites of saxitoxin analogues in bivalves contaminated by Gymnodinium catenatum. Toxicon. 55, 162-165

Visciano, P., Schirone, M., Berti, M., Milandri, A., Tofalo, R. and Suzzi, G. (2016) Marine biotoxins: occurrence, toxicity, regulatory limits and reference methods. Front. Microbio.7:1051, doi: 10.3389/fmicb.2016.01051

Wiese, M., D’Agnostino, P.M., Mihali, T.K., Moffitt, M.C., Neilan, B.A., (2010). Neurotoxic alkaloids: saxitoxin and its analogs. Marine Drugs 8, 2185-2211

Wu, Z., Xie, L., Xia, G., Zhang, J., Nie, Y., Hu, J., Wang, S. And Zhang, R. 2005. A new tetrodotoxin-producing actinomycete, Norcardiopsis dassonvillei, isolated from the ovaries of puffer fish Fugu rubripes. Toxicon. 45: 851-859

Wang, X-J., Yu, R-C., Luo, X., Zhou, M-J. and Lin, X-T. 2008. Toxin-screening and identification of bacteria from highly toxic marine gastropod Nassarius semiplicatus. 52, 5561

Yasumoto, T., Oshima,Y. and Yamaguchi, M. (1978) Occurrence of a new type of shellfish poisoning in the Tohoku district, Nippon Suisan Gakkaishi, 44: 1249-55. 
943 Yasumoto, T., Oshima, Y. and Yamaguchi, M. (1979) Occurrence of a new type of toxic 944 shellfish in Japan and chemical properties of the toxin in D.L. Taylor and H.W. Seliger (eds.) 945 Toxic dinoflagellate blooms, Elsevier, New York, pp. 395-8.

947 Yasumoto, T., Oshima, Y., Sugawara, W., Fukuyo, Y., Oguri, H., Igarishi, T. and Fujita, N. 948 (1980) Identification of Dinophysis fortii as the causative organism of diarrhetic shellfish 949 poisoning. Bull Jpn. Soc. Sci. Fish., 46, 1405-1411

951 Yasumoto, T., Murata, M., Oshima, Y., Sano, M., Matsumoto, G. K. and Clardy, J. (1985)

952 Diarrhetic shellfish toxins, Tetrahedron, 41: 1019-25.

954 Yasumoto, Y., Seino, N., Murakami, Y. and Murata, M. (1987) Toxins produced by benthic 955 dinoflagellates, Biological Bulletin, 172: 128-31 production of Tetrodotoxin and its derivatives. Toxicon. 26(1), 50 
Table 1. MRM transitions used for LC-MS/MS detection and quantitation of PST, TTX and LT analogues, with primary (quantitative) transitions highlighted in bold

\begin{tabular}{|c|c|c|}
\hline Analogue & ESI+ Transition & ESI- Transition \\
\hline STX & $300.1>204.1,138.0$ & \\
\hline NEO & $316.1>126.1,220.1$ & \\
\hline dcSTX & $257.1>126.1,222.0$ & \\
\hline dcNEO & 273.1>126.1,225.1 & \\
\hline doSTX & $241.1>60.0,206.1$ & \\
\hline TTX & $320.1>302.1,162.1$ & \\
\hline GTX2 & & $394.1>351.1,333.1$ \\
\hline GTX3 & $396.1>298.1$ & $394.1>333.1$ \\
\hline GTX1 & & $410.1>367.1,349.1$ \\
\hline GTX4 & $412.1>314.1$ & $410.1>367.1$ \\
\hline GTX5 & $380.1>300.1$ & $378.1>122$ \\
\hline GTX6 & $396.1>316.1$ & $394.1>122$ \\
\hline dcGTX2 & & 351.1>164.0,333.1 \\
\hline dcGTX3 & $353.1>255.1$ & $351.1>333.1$ \\
\hline dcGTX1 & & $367.1>274.1,349.1$ \\
\hline dcGTX4 & $369.1>271.1$ & $367.1>349.1$ \\
\hline C1 & & 474.1>122.0,351.1 \\
\hline $\mathrm{C2}$ & $396.1>298.1$ & $474.1>122.0$ \\
\hline C3 & $412.1>332.1$ & $490.1>410.1$ \\
\hline $\mathrm{C} 4$ & $412.1>314.1$ & $490.1>, 392.1$ \\
\hline OA, DTX2 & & $803.5>255.1,113$ \\
\hline DTX1 & & $817.5>255.1,113$ \\
\hline YTX & & $570.5>467.4,396.2$ \\
\hline Homo YTX & & $577.5>474.2,403.2$ \\
\hline 45 OH YTX & & $578.5>467.4,396.2$ \\
\hline $45 \mathrm{OH}$ homo YTX & & $585.5>474.2,403.2$ \\
\hline AZA1 & $842.5>654.4,362.3$ & \\
\hline AZA2 & $856.6>654.4,362.3$ & \\
\hline AZA3 & $828.5>658.4,362.3$ & \\
\hline PTX1, PTX11 & $892.5>821.5,213.1$ & \\
\hline PTX2 & $876.3>823.5,213.1$ & \\
\hline SPX1 & $692.5>164.1,444.3$ & \\
\hline GYM & $508.4>136.1,162.1$ & \\
\hline 20-Me SPX-G* & $706.5>164.2$ & \\
\hline
\end{tabular}

*Only 1 MRM used for identification and quantitation 
Table 2. Toxicity equivalent factors (TEFs) used in study.

\begin{tabular}{ll}
\hline Toxin & TEF \\
\hline C1 & 0.01 \\
C2 & 0.1 \\
C3 & 0.02 \\
C4 & 0.1 \\
dcGTX2 & 0.2 \\
dcGTX3 & 0.4 \\
dcGTX1 & $0.5^{1}$ \\
dcGTX4 & $0.5^{1}$ \\
GTX2 & 0.4 \\
GTX3 & 0.6 \\
GTX1 & 1 \\
GTX4 & 0.7 \\
GTX5 & 0.1 \\
GTX6 & 0.1 \\
doSTX & $0.05^{2}$ \\
dcSTX & 1 \\
dcNEO & 0.4 \\
STX & 1 \\
NEO & 1 \\
OA & 1 \\
DTX1 & 1 \\
DTX2 & 0.6 \\
PTX2 & 1 \\
AZA1 & 1 \\
AZA2 & 1.8 \\
AZA3 & 1.4 \\
YTX & 1 \\
homo YTX & 1 \\
45-OH YTX & 1 \\
45-OH homo YTX & 0.5 \\
2- doGTX1 and dcGTX4 based on assumed toxicity equivalency factors (Sullivan, 1983) \\
\end{tabular}




\section{ACCEPTED MANUSCRIPT}

Figure 1. Map showing location of shellfish harvesting areas and photos of four marine monitoring points for bivalve molluscs sampled during this study a) Gangoli b) Mulki c) Someshwar d) Sasthana

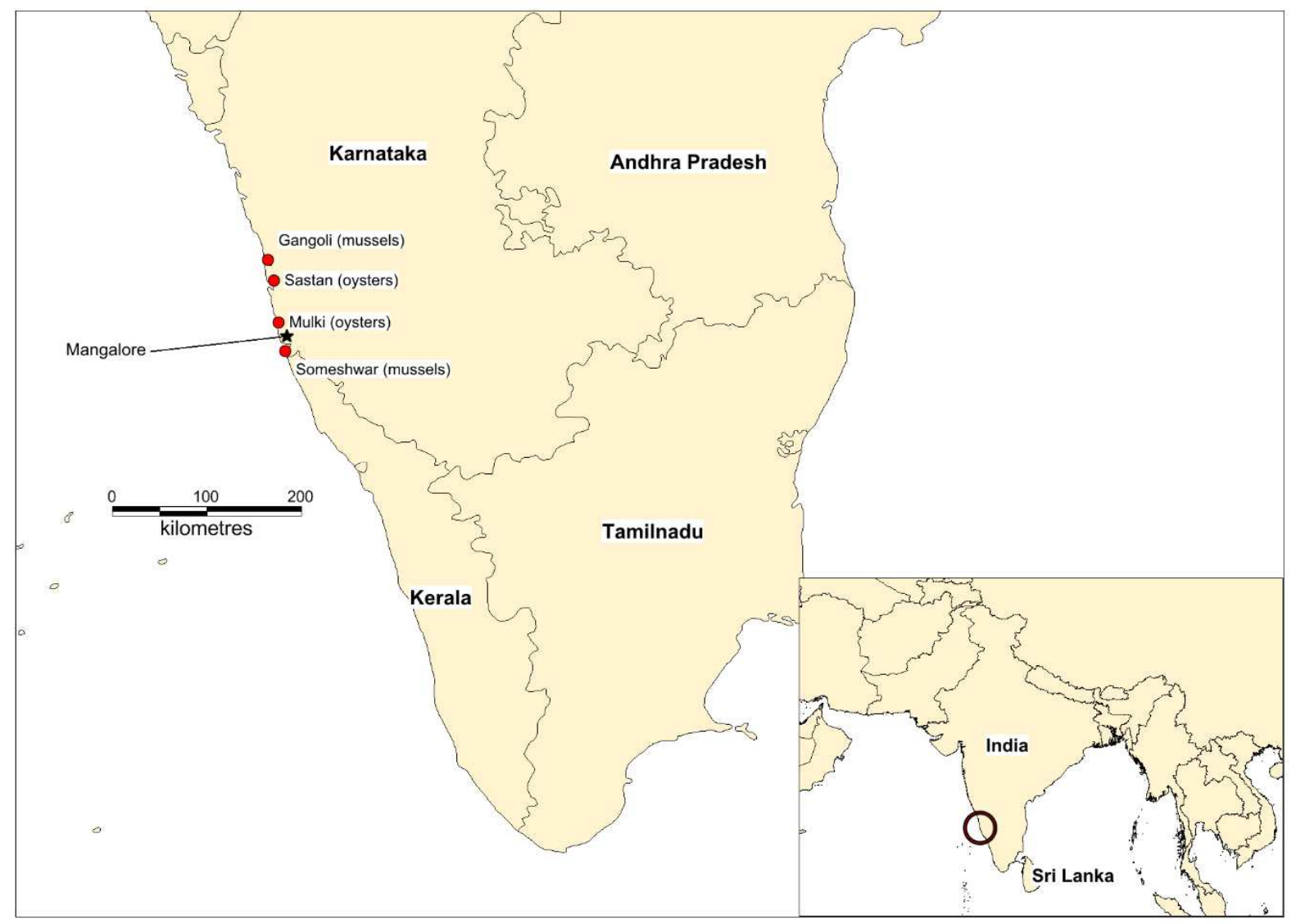

a) Gangoli (mussels)

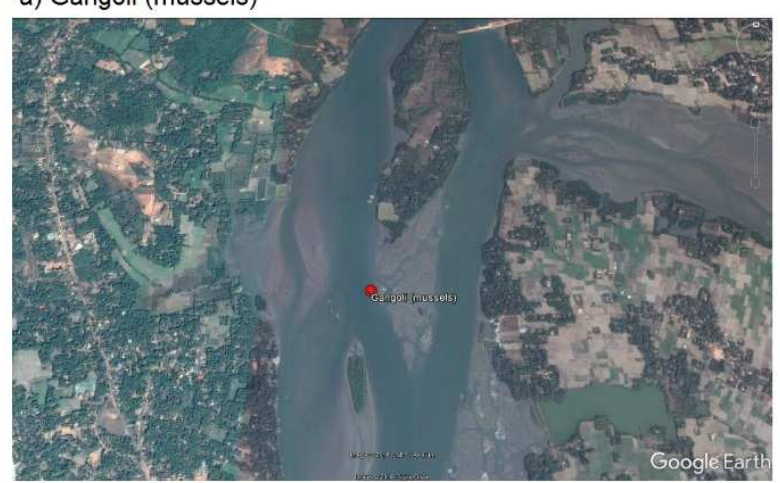

c) Someshwar (mussels)

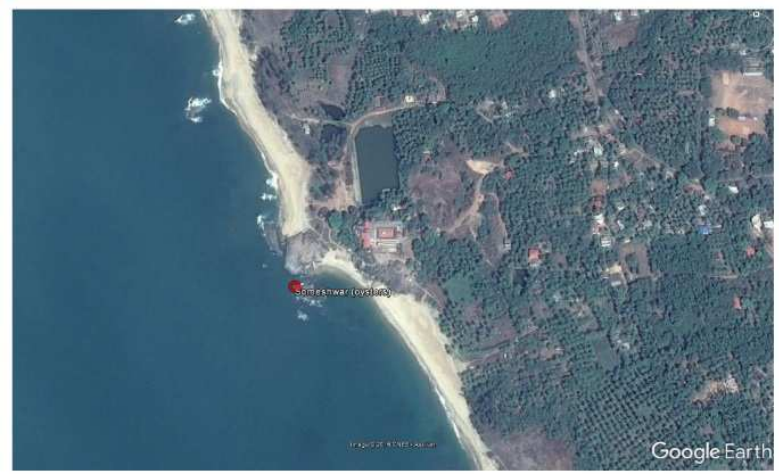

b) Mulki (oysters)

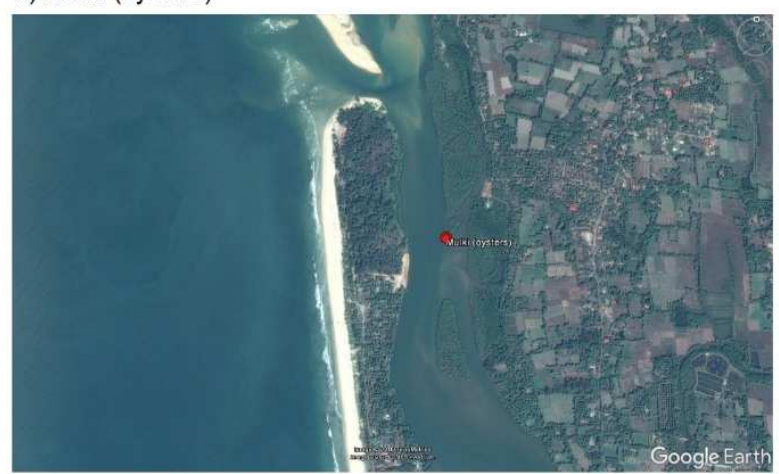

d) Sasthana (oysters)

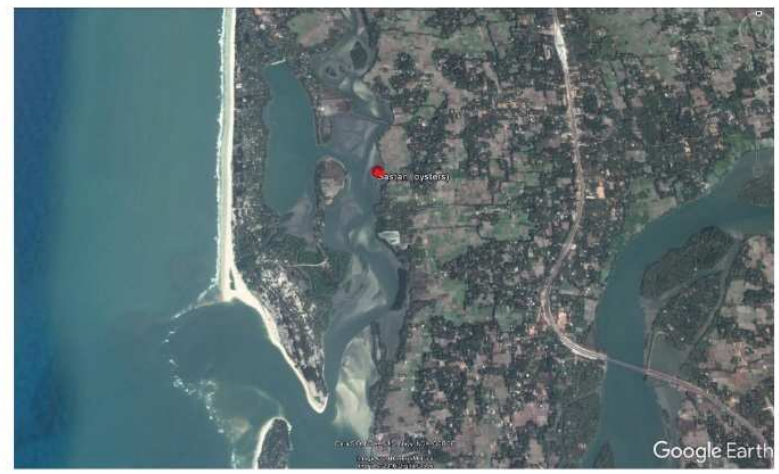


Figure 2. Summary of total PST concentrations ( $\mu \mathrm{g} \mathrm{STX} \mathrm{eq/kg)} \mathrm{quantified} \mathrm{in} \mathrm{mussels} \mathrm{and} \mathrm{oysters} \mathrm{from}$ four shellfish harvesting areas in Mangalore

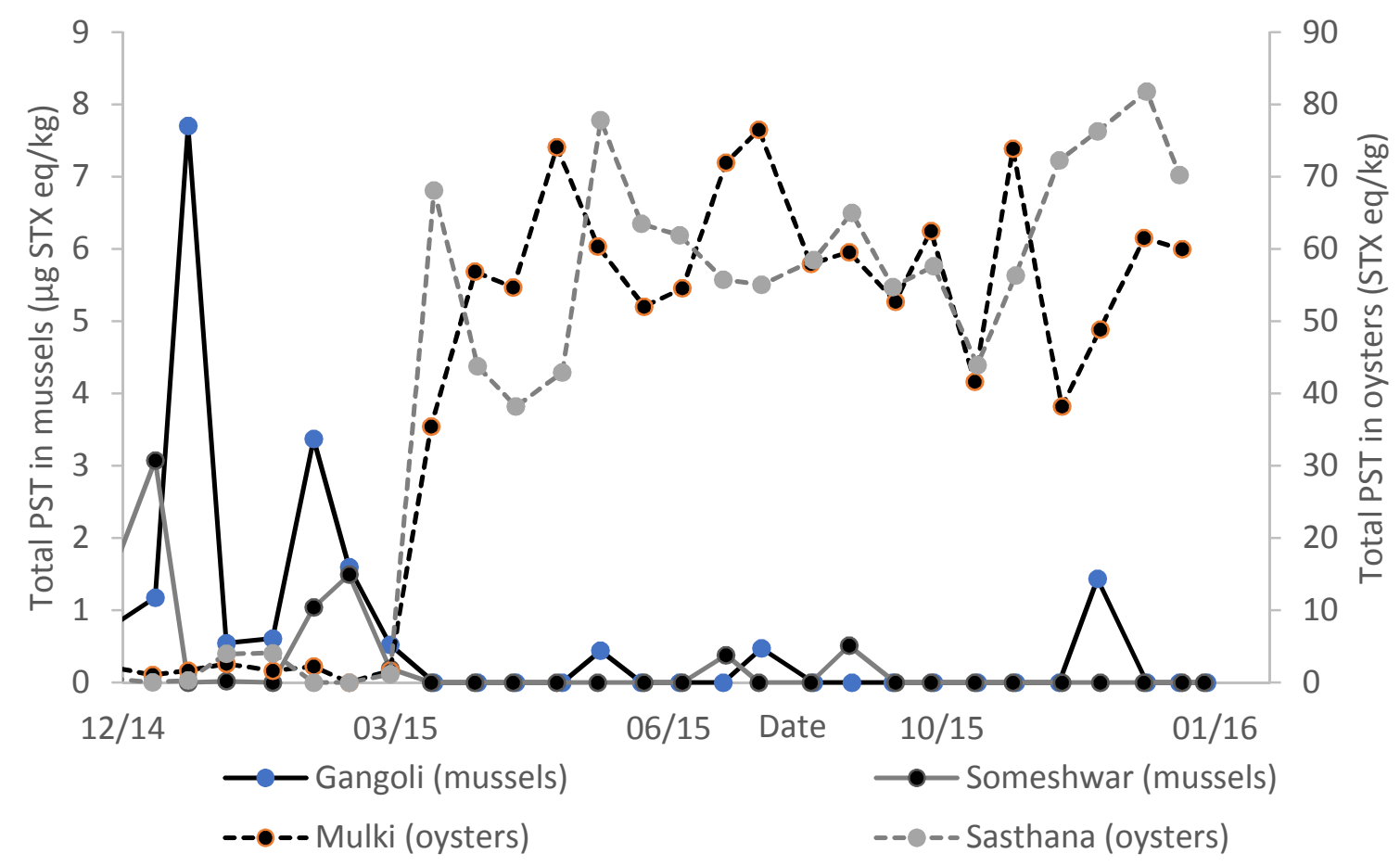


Figure 3. PST profiles in oysters from Mulki and Sasthana

0.80

0.70

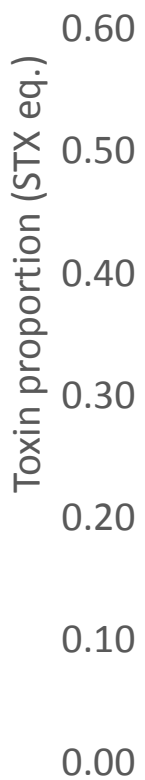

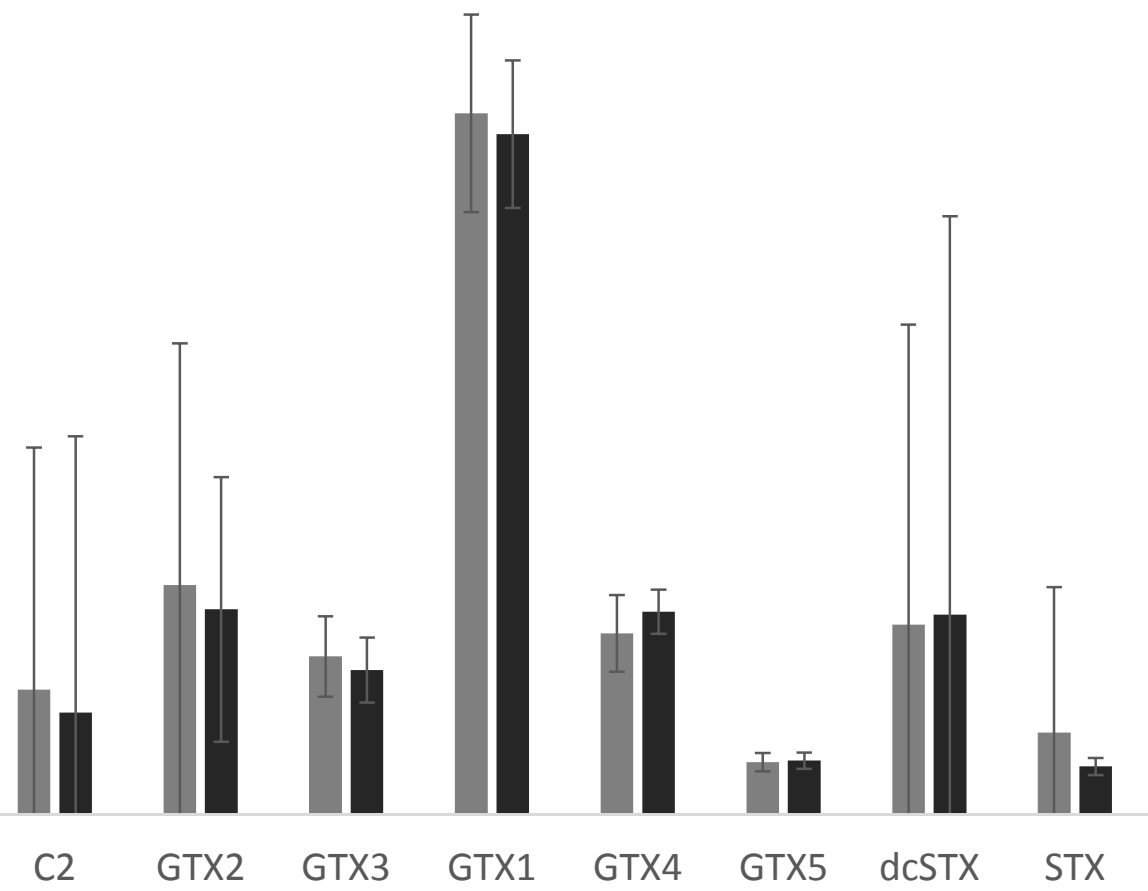

- Mulki oysters $\quad$ Sasthana oysters 
Figure 4. Summary of GYM concentrations $(\mu \mathrm{g} / \mathrm{kg})$ quantified in mussels and oysters from four shellfish harvesting areas in Mangalore

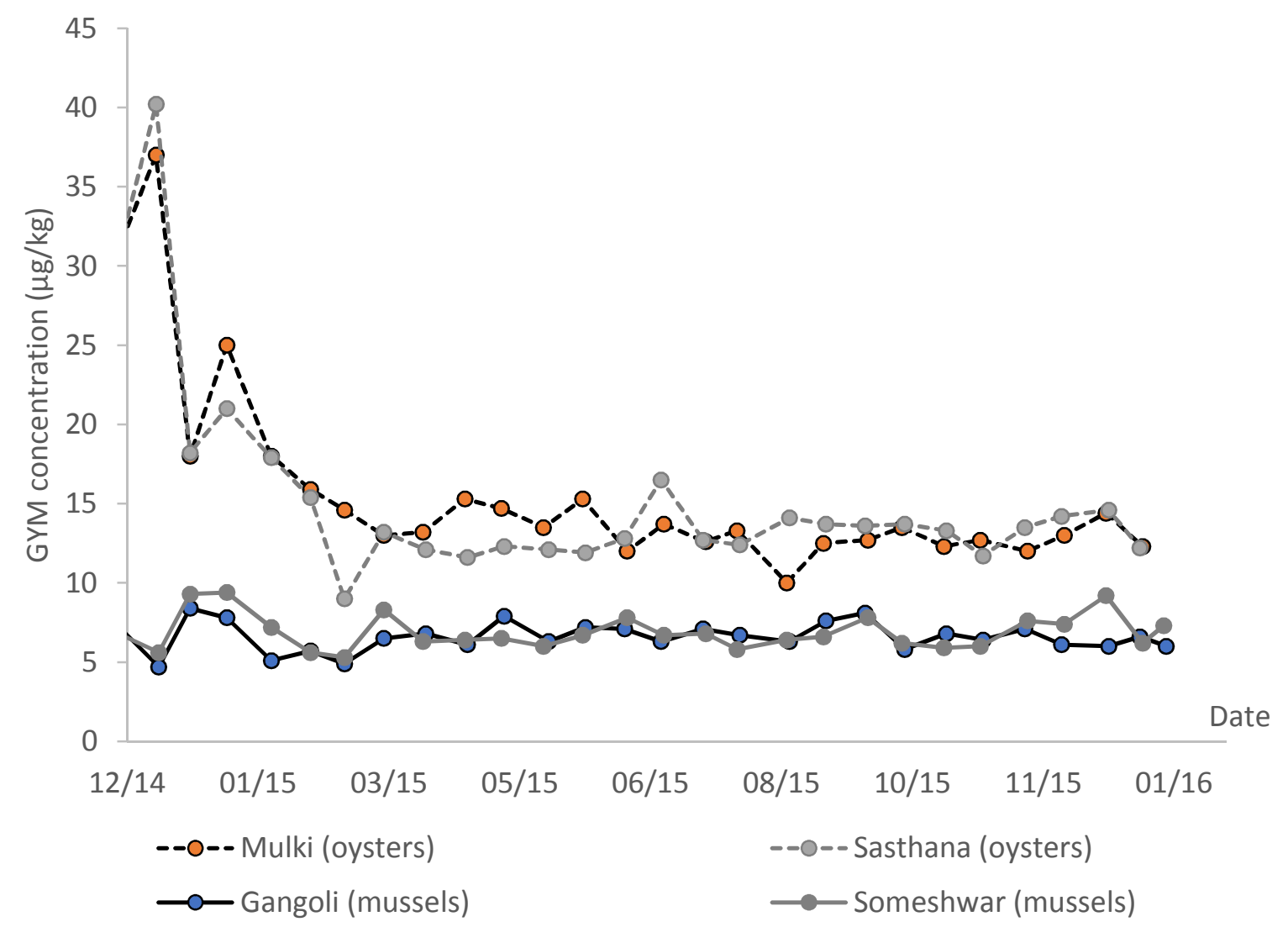


- First ever systematic study of Indian shellfish toxins

- Application of chemical detection monitoring

- Assessment of marine biotoxins

- PST temporal variability

- PST profile assessment 
Cefas

Cefas

Barrack Road

Weymouth

DT4 8UB

$22^{\text {nd }}$ Sept 2017

\section{Ethical Statement}

To whom it may concern,

All authors have agreed to this submission and the final manuscript has been seen by all authors. This paper has not been published and the authors will not permit its submission or publication elsewhere before it is accepted or declined by this journal.

Dr Andrew D. Turner

Andrew.turner@cefas.co.uk 